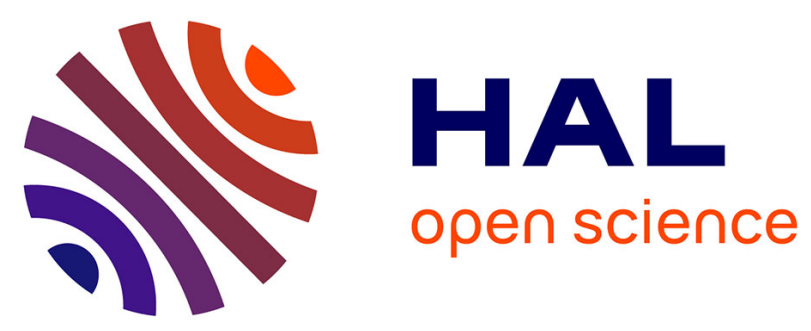

\title{
Thiophene fused indenocorannulenes: synthesis, variable emission, and exceptional chiral configurational stability
} Xiaoqi Tian, Suchaya Chaiworn, Jun Xu, Nicolas Vanthuyne, Kim K Baldridge, Jay S Siegel

\section{- To cite this version:}

Xiaoqi Tian, Suchaya Chaiworn, Jun Xu, Nicolas Vanthuyne, Kim K Baldridge, et al.. Thiophene fused indenocorannulenes: synthesis, variable emission, and exceptional chiral configurational stability. Organic Chemistry Frontiers, 2021, 8 (14), pp.3653-3658. 10.1039/d1qo00596k . hal-03516904

\author{
HAL Id: hal-03516904 \\ https://hal.science/hal-03516904
}

Submitted on 7 Jan 2022

HAL is a multi-disciplinary open access archive for the deposit and dissemination of scientific research documents, whether they are published or not. The documents may come from teaching and research institutions in France or abroad, or from public or private research centers.
L'archive ouverte pluridisciplinaire HAL, est destinée au dépôt et à la diffusion de documents scientifiques de niveau recherche, publiés ou non, émanant des établissements d'enseignement et de recherche français ou étrangers, des laboratoires publics ou privés. 


\title{
Thiophene fused indenocorannulenes: synthesis, variable emission, and exceptional chiral configurational stability $\dagger$
}

\author{
Xiaoqi Tian, ${ }^{a}$ Suchaya Chaiworn, ${ }^{\mathrm{a}} \mathrm{Jun} \mathrm{Xu},{ }^{a}$ Nicolas Vanthuyne, (D) ${ }^{\mathrm{b}}$ \\ Kim K. Baldridge (D)*a and Jay S. Siegel (iD *a

\begin{abstract}
A set of thiophene fused indenocorannulenes (TFICs) was synthesized and characterized by X-ray crystallography, electrochemical, and photophysical methods. Two chiral derivatives were resolved and their absolute configurations defined by Flack analysis (12a) and by comparison of experimental VCD/ECD spectra with hybrid DFT methods (12b and $\mathbf{3 a}$ ). The emission wavelengths of $\mathbf{1 3}$ compounds were compared and varied over $220 \mathrm{~nm}$ (emission colors from violet to red). The bowl-inversion activation barrier of 12 was determined to be $192.7 \mathrm{~kJ} \mathrm{~mol}^{-1}$, corresponding to a configurational stability of weeks at $200^{\circ} \mathrm{C}$; on par with the highest helicene and phosphine values.
\end{abstract}

\section{Introduction}

Polynuclear aromatic hydrocarbon (PAH) networks can be seen as "Loschmidt" graphs in which cyclic 6-atom "elements" map on to the graph vertices. ${ }^{1-3}$ "Isosteric" replacement of benzene by a heterocycle (e.g. thiophene) yields a set of hydrocarbon/ heterocycles appropriate for systematic structure-property comparisons. ${ }^{4}$ PAHs that comprise thiophene in this manner manifest electrochemical and photochemical properties suitable for organic light-emitting diode (OLED), solar cell, conducting polymer, and field-effect transistor development. ${ }^{5-10}$ Reports of curved-PAHs in this family are sparse in part due to synthetic effort and accessibility. ${ }^{11-13}$ Furthermore, the reported thiophene fused corannulenes (Fig. 1) derive from benzocorannulene graphs, which typically have shallow bowl depths and therefore small energy barriers to bowl inversion. Thiophenes derived from indenocorannulene graphs (defined here as thiophene fused indenocorannulenes or TFICs) possess deeper bowl depths and higher energy barriers to bowl inversion, due to the $[a, c]$-indeno fusion. Studies of the parent PAHs augur resolvable configurationally stable chiral TFICs suitable for materials research as well as for testing methods in the assignment of molecular absolute configuration.

${ }^{a}$ Health Science Platform, Tianjin University, 92 Weijin Road, Nankai District, 300072 Tianjin, China.E-mail: sdean_spst@tju.edu.cn

${ }^{b}$ Aix Marseille Université, CNRS, Centrale Marseille, iSm2, 13007 Marseille, France

\section{Results and discussion}

Precursors $(\mathbf{2}, \mathbf{5}, \mathbf{8}, \mathbf{1 1})$ of TFICs $(\mathbf{3}, \mathbf{6}, \mathbf{9}, \mathbf{1 2})$ were synthesized from iodocorannulene (1), ${ }^{14,15}$ dibromodimethylcorannulene (4),$^{16} \quad$ 4,9-dibromocorannulene-1,2-dicarboximide $(7)^{17}$ and 4-bromo-9-(2-chloro-3-pyridyl)corannulene-1,2-dicarboximide (10) through Suzuki coupling reactions, ${ }^{18,19}$ respectively. Palladium-catalyzed intramolecular ring closure of 2, 5, 8 and 11 produced 3, 6, 9, and $\mathbf{1 2}$ in $85 \%, 35 \%, 35 \%, 40 \%$ yield (Scheme 1). It is worth mentioning that 0.1 eq. $\mathrm{Pd}\left(\mathrm{PCy}_{3}\right)_{2} \mathrm{Cl}_{2}$ for each indeno moiety were required in the synthesis of azaindenocorannulenes, ${ }^{20}$ while 0.2 eq. $\mathrm{Pd}\left(\mathrm{PCy}_{3}\right)_{2} \mathrm{Cl}_{2}$ is required for each indeno moiety in the synthesis of the four TFICs.

Single crystals suitable for X-ray crystallographic analysis were obtained for 3, 6 (deuterated chloroform/hexane), and $\mathbf{1 2}$ (dichloromethane) (Fig. 2). Consistent with isosteric replacement design principle, the bowl depth and POAV angle of 3 $\left(1.06 \AA, 9.6^{\circ}\right), 6\left(1.18 \AA, 10.6^{\circ}\right)$, and $12\left(1.18 \AA, 10.5^{\circ}\right)$ are larger than that of corannulene $\left(0.875 \AA, 8.3^{\circ}\right)$ and approximately that of $22\left(1.06 \AA, 9.7^{\circ}\right),{ }^{21}$ dimethyl diindenocorannulene 19 $\left(1.177 \AA, 10.6^{\circ}\right),{ }^{22} \mathrm{~N}$-alkylmaleimide diindenocorannulene 18

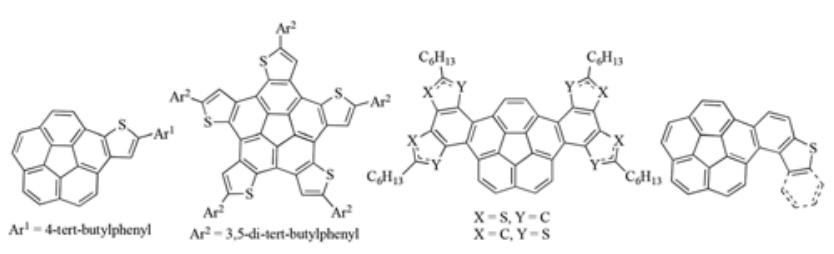

Fig. 1 Representative thiophene fused corannulene structures. 


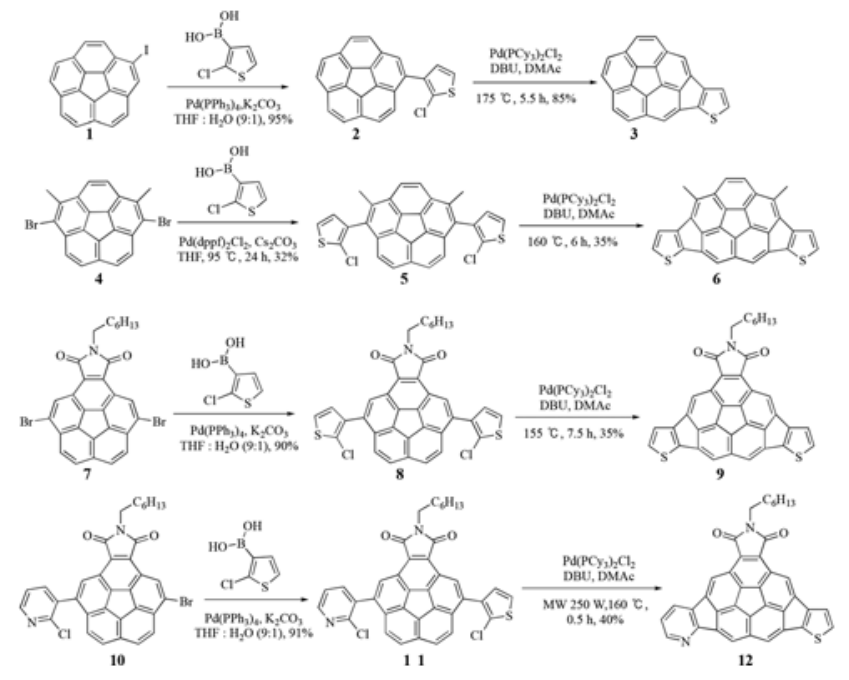

Scheme 1 The synthetic route for compounds 3, 6, 9 and 12.
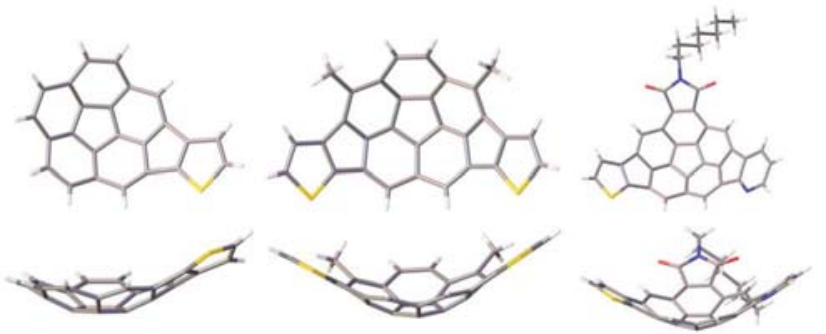

Fig. 2 X-ray crystallographic structures of 3, 6 and 12, viewed from rim to hub atoms.

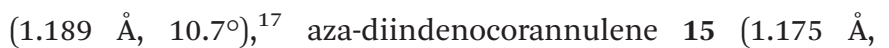
$\left.10.6^{\circ}\right),{ }^{20}$ respective to the number of ring fusions (Table 1$)$.

All three compounds adopt an orthorhombic (3-Pna $2_{1}, 6$ Pnma $)$ or a monoclinic $\left(\mathbf{1 2}-P 2_{1}\right)$ space group and all show bowl-in-bowl columnar assemblies along one stacking axis (Fig. 3). Racemic 3 presents as a twin crystal in the polar orthorhombic space group $P_{n a 2}$, with two molecules in the asymmetric unit. Although the columns are pointing in the same direction both asymmetric molecular sites are equally likely to have left as right-handed molecules without regular order. The unit cell of 6 is nonpolar in the orthorhombic space group

Table 1 Bowl depths, POAV hub angles, space group of 3, 6, 12 and related compounds

\begin{tabular}{llll}
\hline Cmpnd & Bowl depth $(\AA)$ & POAV $_{\text {hub }}$ angle & Space group \\
\hline $\mathbf{3}$ & $1.06 \pm 0.02(1.10)^{a}$ & $9.6 \pm 0.4(10.1)$ & Pna $2_{1}$ \\
$\mathbf{6}$ & $1.18 \pm 0.04(1.22)$ & $10.6 \pm 0.7(10.8)$ & Pnma \\
$\mathbf{1 2}$ & $1.18 \pm 0.04(1.21)$ & $10.5 \pm 1.0(10.8)$ & $P 2_{1}$ \\
$\mathbf{2 2}^{21}$ & $1.06 \pm 0.05(1.06)$ & $9.7 \pm 0.9(9.7)$ & $P 2_{1} / n$ \\
$\mathbf{1 9}^{22}$ & $1.18 \pm 0.04(1.22)$ & $10.6 \pm 0.6(10.9)$ & $\mathrm{Cmc2_{1 }}$ \\
$\mathbf{1 8}^{17}$ & $1.19 \pm 0.04(1.22)$ & $10.6 \pm 0.7(10.9)$ & $\mathrm{Pbca}$ \\
$\mathbf{1 5}^{20}$ & $1.18 \pm 0.04(1.22)$ & $10.6 \pm 0.7(10.9)$ & $P 1$
\end{tabular}

${ }^{a}$ B97-D/Def2-TZVPP optimized results reported in parentheses.
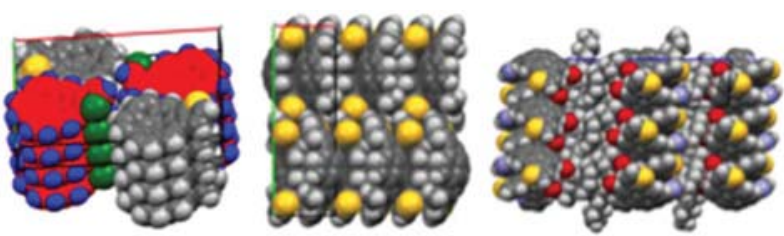

Fig. 3 Crystal packing of 3, 6 and 12a.

Pnma. The packing structure comprises columns in which all the molecules in one any column are oriented along the $c$-axis in the same direction whereas adjacent columns point in opposing directions along the $c$ axis.

Resolution of $\mathbf{1 2}$ by HPLC over chiral support (Chiralpak ID) allowed the study of a crystal from the first eluted fraction (12a). Enantiopure 12a presents in the monoclinic $P 2_{1}$ space group $(Z=8)$ as a chiral anti-parallel columnar structure, with a Flack analysis parameter value of $0.06(4)$, supporting the absolute configuration assignment as shown in Fig. 7. Enantiomeric resolution of 3 by HPLC over chiral support (Chiralpak IG) did not yield crystals suitable for Flack analysis.

Having the pure enantiomers in hand raises questions of how to correlate the 3-dimensional structure to the physical samples and what if any configurational assignments can be made. Fundamental flaws in CIP nomenclature make it unsuitable for universal configurational assignments. Nonetheless, an ad hoc assignment can be made on the basis of a reference model. In the case of 3 , the previously defined 乒/乓 descriptors apply; ${ }^{15}$ however, 12 presents additional problems, to be discuss in detail elsewhere. A convenient tetrahedral model comes from assigning the hub ring, the dicarboxyimide, the thiophene, and the pyridine, as vertices. Viewing the bowl from its convex side (from hub toward rim) the remaining three vertices can be rank ordered to distinguish enantiomeric geometries $R / S$ (Fig. 4), without asserting any fundamental transferrable configurational classification.

A combination of experimental and theoretical ECD and VCD spectra have been used as a powerful way to assign absolute configuration in the absence of X-ray analysis. ${ }^{23}$ Accordingly, the VCD spectra of two enantiomers of 3 and $\mathbf{1 2}$ were measured in $\mathrm{CHBr}_{3}$ and compared with B97-D/Def2$\operatorname{TZVPP}\left(\mathrm{CHBr}_{3}\right)$ determined spectra. Comparison of the $1200-1550 \mathrm{~cm}^{-1}$ regions in the spectra were used to make configurational assignment (Fig. 5). The calculated VCD spectra of 3- 乒 and 12-S match the VCD spectra of 3a and $12 \mathbf{b}$, respectively. The ECD of the two enantiomers of 3 and 12 were additionally measured in $\mathrm{CH}_{3} \mathrm{CN}$ and compared with TD-

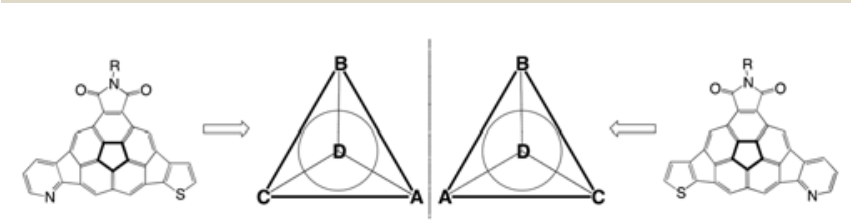

Fig. 4 Ad Hoc configurational model. 

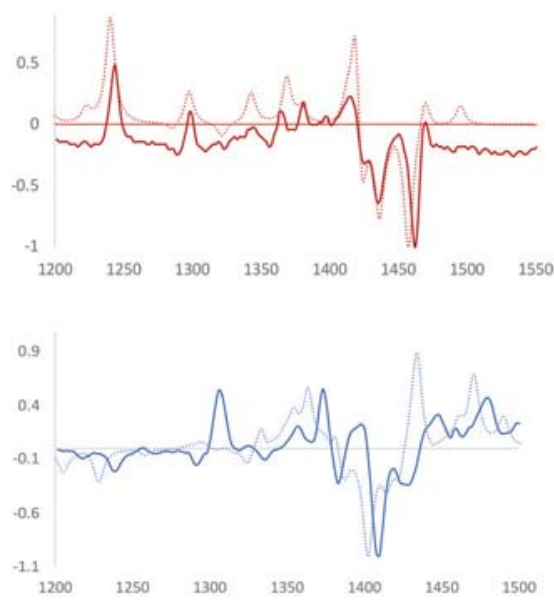

Fig. 5 Experimental and B97-D/Def2-TZVPP $\left(\mathrm{CHBr}_{3}\right)$ VCD spectra of 3a (red) and 12b (blue).

wB97xD/Def2-TZVPP $\left(\mathrm{CH}_{3} \mathrm{CN}\right)$ determined spectra (Fig. 6). The calculated ECD spectra of 3- 兵 and 12- $S$ agree well with the corresponding experimental spectra of $\mathbf{3 a}$ and $\mathbf{1 2} \mathbf{b}$, respectively. From the Flack analysis of the X-ray crystal structure of 12a, the absolute configuration was assigned as 12- $R$, ergo the configuration of $\mathbf{1 2 b}$ as $\mathbf{1 2}-S$, and supporting the computational configurational assignment (Fig. 7).

The bowl inversion barrier of $\mathbf{3}$ and $\mathbf{1 2}$ could be determined by kinetic studies on the first order decay of optical activity. The bowl inversion energy of 3 varies slightly in differing solvents, from 114-118 kJ mol${ }^{-1}$ (Table 2), but in good agreement with the computational data. Although the bowl depth of 12 $(1.18 \AA)$ is only about $12 \%$ larger than $3(1.06 \AA)$, the $x^{4}$ relationship between bowl depth and barrier would predict a $55-60 \%$ increase in the barrier (ca. $\left.185 \mathrm{~kJ} \mathrm{~mol}^{-1}\right) .{ }^{24}$ Kinetic studies on the first order decay of optical activity in 12a reveal a half-life of 1113 hours at $228{ }^{\circ} \mathrm{C}$, which corresponds to a bowl inversion energy of $192.7 \mathrm{~kJ} \mathrm{~mol}^{-1}$ in good agreement
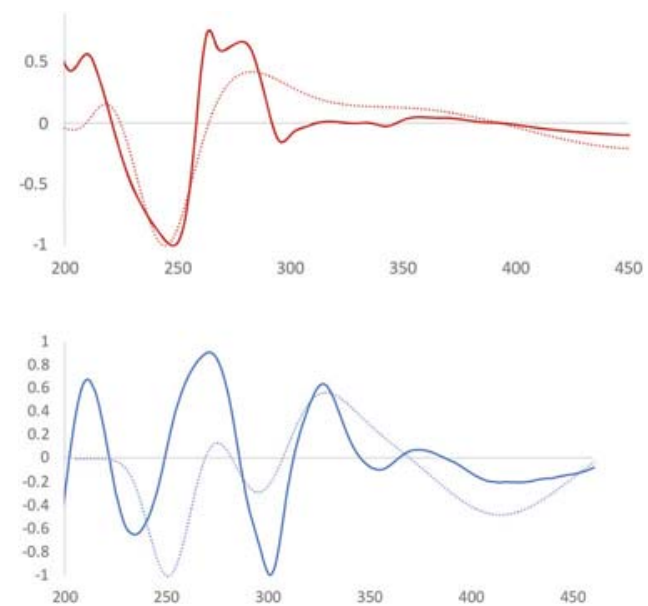

Fig. 6 Experimental and TD-wB97xD/Def2-TZVPP $\left(\mathrm{CH}_{3} \mathrm{CN}\right) \quad$ ECD spectra of $3 a$ (red) and $12 b$ (blue).

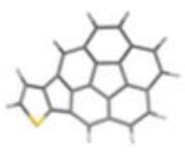

a
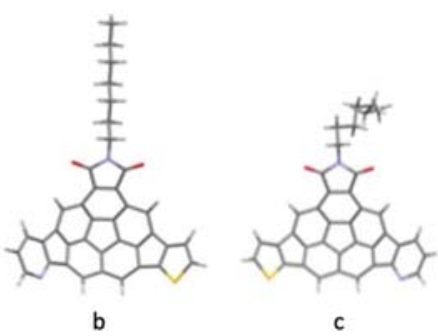

Fig. 7 ( $a$ and b) B97-D/Def2-TZVPP optimized structures for 3a and $12 b$, and (c) X-ray determined crystal structure of $12 a$.

Table 2 Rate constants, bowl inversion barriers, and half-lives of 3 and 12

\begin{tabular}{lllll}
\hline Cmpnd & $\mathbf{3}$ & $\mathbf{3}$ & $\mathbf{3}$ & $\mathbf{1 2}$ \\
\hline$k\left(\mathrm{~s}^{-1}\right)$ & $6.43 \times 10^{-5}$ & $3.63 \times 10^{-5}$ & $3.72 \times 10^{-5}$ & $8.64 \times 10^{-8}$ \\
$t_{1 / 2}($ hours $)$ & 1.5 & 2.7 & 2.6 & 1113 \\
$\Delta G\left(\mathrm{~kJ} \mathrm{~mol}^{-1}\right)$ & 114.7 & 117.3 & 115.9 & 192.7 \\
$\mathrm{Calcd}^{a}$ & 112.2 & 113.1 & $\mathrm{~N}^{b}$ & 196.7 \\
$T(\mathrm{~K})$ & 351 & 354 & 350 & 501 \\
Solvent & $\mathrm{EtOH}$ & $\mathrm{CYH}$ & $\mathrm{CCl}_{4}$ & $\mathrm{Ph}_{2} \mathrm{O}$
\end{tabular}

${ }^{a}$ B97-D/Def2-TZVPP(solvent) with solvent as in experiment. ${ }^{b}$ Not determined.

with the B97-D/Def2-TZVPP prediction of $196.7 \mathrm{~kJ} \mathrm{~mol}^{-1}$ and consistent with the $x^{4}$ analytical relationship between bowl depth and inversion barrier.

Compounds 3, 6, 9 and 12 possess highly conjugated structures, the photophysical properties of which are reported in Table 3. In their absorption spectra, compounds 3 and 6 exhibit two main absorption maxima at 254 and $344 \mathrm{~nm}$, respectively. Compounds $\mathbf{9}$ and $\mathbf{1 2}$ exhibit two main absorption maxima at 249, $337 \mathrm{~nm}$ and 272, $328 \mathrm{~nm}$, respectively. The emission spectra shows that compound 6 has the longest emission wavelength at $657 \mathrm{~nm}$, and compound 3 has the smallest emission wavelength at $606 \mathrm{~nm}$ (Fig. 8). The emission wavelength of these thiophene fused indenocorannulenes red shift up to $80 \mathrm{~nm}$ compared with the parent indenocorannulenes $(\mathbf{1 8}, \mathbf{2 0})$ and aza-indenocorannulenes $(\mathbf{1 5}, \mathbf{1 7})$ due to the electron-rich property of the thiophene moiety. ${ }^{17,20}$ Comparison of the emission wavelengths of the $\mathbf{1 3}$ related compounds reveal that their emission colors systematically vary over $220 \mathrm{~nm}$, from violet (corannulene), to yellow ([aza]/indenocorannulenes), to red (TFICs) (Fig. 9 and 10). Fluorescence quantum yields of the four compounds are all less than $0.55 \%$.

The cyclic voltammograms of 3, 6, 9 and $\mathbf{1 2}$ exhibit a semireversible to reversible reduction at $E_{1 / 2}=-1.94 \mathrm{eV},-1.82 \mathrm{eV}$,

Table 3 Experimental photophysical properties for 3, 6, 9 and 12

\begin{tabular}{lllll}
\hline Cmpnd & Em [Ex] (QY\%) & $\lambda_{\text {abs }}$ & $\lambda_{\text {onset }}$ & $E_{\text {g }}$ \\
\hline $\mathbf{3}$ & $606[342](0.4 \%)$ & 344,306 & $360 \pm 5$ & $3.45 \pm 0.05$ \\
$\mathbf{6}$ & $657[360](0.2 \%)$ & 359,344 & $375 \pm 5$ & $3.30 \pm 0.05$ \\
$\mathbf{9}$ & $638[336](0.5 \%)$ & 337 & $385 \pm 5$ & $3.20 \pm 0.05$ \\
$\mathbf{1 2}$ & $629[345](0.3 \%)$ & 328 & $385 \pm 5$ & $3.20 \pm 0.05$
\end{tabular}




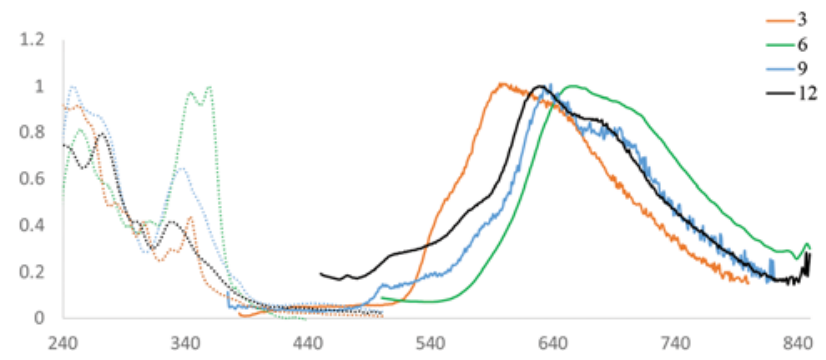

Fig. 8 UV and fluorescence spectra of 3, 6, 9 and 12.

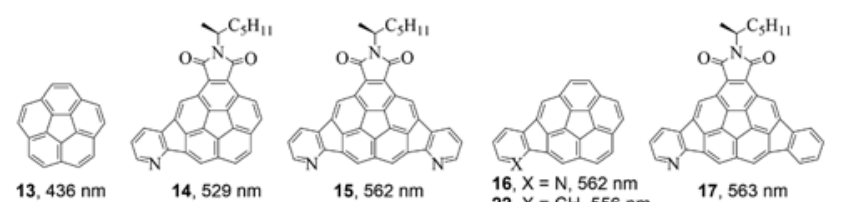

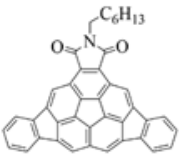

$18,569 \mathrm{~nm}$

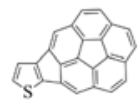

$3,606 \mathrm{~nm}$

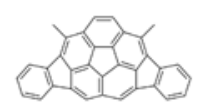

$19,575 \mathrm{~nm}$

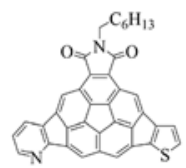

$12,629 \mathrm{~nm}$

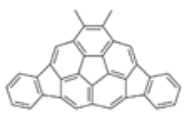

$20,579 \mathrm{~nm}$

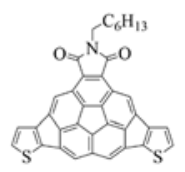

$9,638 \mathrm{~nm}$

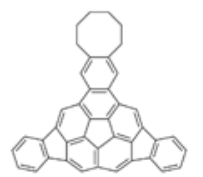

$21,592 \mathrm{~nm}$

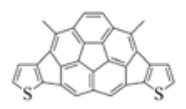

$6,657 \mathrm{~nm}$
Fig. 9 Related indenocorannulenes together with their emission wavelengths.

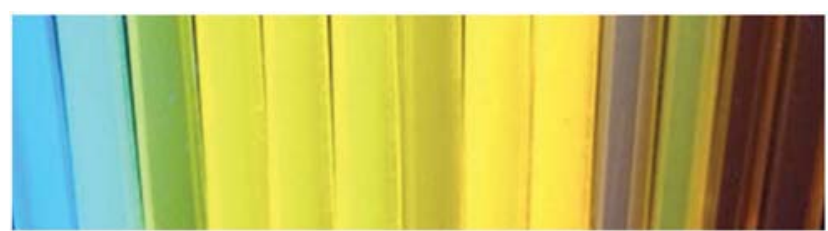

Fig. 10 Indenocorannulene derivatives (13-21, 3, 12, 9, 6) under $365 \mathrm{~nm}$ lamp, in THF, $2 \mathrm{mg} \mathrm{mL}^{-1}$.

$-1.51 \mathrm{eV}$ and $-1.46 \mathrm{eV}$ respectively (Table 4). Compound 12 has the smallest first reduction potential at $-1.54 \mathrm{eV}$. The first reduction potentials of $\mathbf{9}$ and $\mathbf{1 2}$ are much smaller than $\mathbf{3}$ and 6. Analysis of the values of $I_{\mathrm{pa}} / I_{\mathrm{pc}}$ reveal the reversibility of 3 and $\mathbf{9}$ to be superior to that of $\mathbf{6}$ and $\mathbf{1 2}$.

It has been suggested that thiophene is a close analogue to benzene. ${ }^{25-28}$ The hypothesis can be tested in an electrochemical context for TFICs by comparing the first reduction potentials of the four compounds with the respective parent indenocorannulenes $(\mathbf{3} / \mathbf{2 2}, \mathbf{6 / 1 9}, \mathbf{9 / 1 8}, \mathbf{1 2} / \mathbf{1 7}) .{ }^{17,20,22}$ With regard to first reduction potentials, the TFICs are similar to their respective parent indenocorannulenes however the degree of reversibility seems to be worse; therefore the isosteric/isoelectronic assumption appears to hold also for this additional though limited set of compounds.
Table $4 E_{\mathrm{c}}^{*}(\mathrm{~V}), E_{1 / 2}(\mathrm{~V}), I_{\mathrm{pa}} / I_{\mathrm{pc}}$ for $3,6,9,12$ and related compounds

\begin{tabular}{llll}
\hline Cmpnd & $E_{\mathrm{c}}^{*}(\mathrm{eV})^{a}$ & $E_{1 / 2}(\mathrm{eV})$ & $I_{\mathrm{pa}} / I_{\mathrm{pc}}$ \\
\hline $\mathbf{3}$ & $-2.03(-2.02)^{b}$ & -1.94 & 0.84 \\
$\mathbf{2 2}$ & $\mathrm{N}$ & $\mathrm{N}$ \\
$\mathbf{6}$ & $-2.06(-2.06)$ & -1.82 & 0.45 \\
$\mathbf{1 9}$ & $-1.87(-1.93)$ & -1.85 & 0.71 \\
$\mathbf{9}$ & $-1.91(-1.89)$ & -1.51 & 0.84 \\
$\mathbf{1 8}$ & $-1.59(-1.54)$ & -1.51 & 1.15 \\
$\mathbf{1 2}$ & $-1.60(-1.52)$ & -1.46 & 0.42 \\
$\mathbf{1 7}^{20}$ & $-1.54(-1.47)$ & -1.46 & 0.84
\end{tabular}

${ }^{a}$ Solvent: THF; working electrode: glassy carbon; reference electrode: $\mathrm{Ag} / \mathrm{Ag}^{+}$in acetonitrile; counter electrode: platinum wire; scan rate: 0.1 $\mathrm{V} \mathrm{s}^{-1}$; supporting electrolyte: tetrabutylammonium hexafluorophosphate $\left(\mathrm{TBAPF}_{6}\right) \cdot E_{\mathrm{c}}^{*}=$ first reduction potential, $E_{1 / 2}=$ half-wave potential, $I_{\mathrm{pa}}=$ peak anodic current, $I_{\mathrm{pc}}=$ peak cathodic current. ${ }^{b}$ Values in parentheses are B97-D/Def2-TZVPP(THF) calculated values, using $E_{\mathrm{c}}^{\circ}=-\Delta H / n F-\operatorname{Ref}_{\mathrm{Ag} / \mathrm{AgCl}}$, where $n=1, F=1 \mathrm{eV}$.

\section{Conclusions}

A combination of a graph theory approach to the taxonomy of PAHs and the concept of isosteric replacement, led to the design and synthesis of a small set of TFICs including two chiral compounds. Three structures of these were confirmed by X-ray crystal diffraction. The two chiral derivatives 3 and $\mathbf{1 2}$ were resolved and in the case of 12a Flack analysis provided a suggested assignment of configuration. Configurations of the two chiral compounds were also assigned by comparison of the experimental VCD/ECD spectra with that of the computationally predicted spectra. The assignments of VCD/ECD agree well with that of the Flack analysis. The bowl inversion activation energy of 12a reaches an extraordinarily high value $\left(192.7 \mathrm{~kJ} \mathrm{~mol}^{-1}\right)$ that correlates with stability against racemization for days at $200{ }^{\circ} \mathrm{C}$. Such configurational robustness is on par with the highest values reported for helicenes and chiral phosphines. Chiral bowls of this ilk can be prepared in a variety of patterns, and given their exceptional configurational stability, could be useful scaffolds for the development of chiral catalysts, chiroptical materials, and diagnostic/sensing agents. Their electrochemical properties are quite similar with the parent indenocorannulenes, while their emission colors can be systematically varied over $220 \mathrm{~nm}$, from violet (corannulene, 13), to yellow (ICs/AICs), to red (TFICs).

\section{Experimental section}

Unless otherwise stated, all commercially available reagents and solvents were used as received without further purification. Flash chromatography was performed on silica gel 100-200 m. Thin layer chromatography (TLC) was performed on glass backed plates pre-coated with silica (GF254), which were developed using standard visualizing agents. All optical measurements were performed in HPLC grade dichloromethane. UV-Vis measurements were carried out on HITACHI U-3900. Infrared spectra (IR) were recorded on a JASCO FT/ IR-4100 Fourier Transform Infrared Spectrometer. IR frequen- 
cies are given in $\mathrm{cm}^{-1}$. Signal intensities are presented as weak (w), medium (m), strong (s) and very strong (vs). NMR spectra were recorded on Bruker AV-400/600 (400/600 MHz) instruments. The chemical shift $(\delta)$ is shown in ppm and referenced against the corresponding solvent peaks (for $\mathrm{CDCl}_{3},{ }^{1} \mathrm{H}-\mathrm{NMR}$ : $7.26 \mathrm{ppm} ;{ }^{13} \mathrm{C}-\mathrm{NMR}: 77.16 \mathrm{ppm}$ ). Data is reported as follows: chemical shift in ppm, multiplicity ( $\mathrm{s}=$ singlet, $\mathrm{d}=$ doublet, $\mathrm{t}=$ triplet, $\mathrm{q}=$ quartet, $\mathrm{m}=$ multiplet, $\mathrm{dd}=$ doublet of doublet, $\mathrm{dt}$ $=$ doublet of triplet), coupling constant $(J)$ in $\mathrm{Hz}$, and integration. Fluorescence excitation/emission measurements were carried on Edinburgh FLS980 spectrophotometer, using $450 \mathrm{~W}$ Xenon arc lamp, with excitation and emission slit widths at $1 \mathrm{~nm}$. Emission spectra were obtained by exciting at the longest excitation maxima wavelength. Fluorescence lifetimes were measured using nanosecond flash lamp with computercontrolled power supply, for solutions with O.D. $\sim 0.1$. Absolute quantum yields were measured using an integrating sphere accessory. Microwave reactions were performed in a CEM Discover Microwave Reactor with integrated active cooling. All cyclic voltammetry measurements were performed using a CHI600E Electrochemical Analyzer, CH Instruments, Inc. and in THF solvent with a scan rate of $0.1 \mathrm{~V} \mathrm{~s}^{-1}$. THF was of HPLC grade and distilled over $\mathrm{CaH}_{2}$ prior to its use. Tetrabutylammonium hexafluorophosphate (TBAH) was used as an electrolyte. Non-Aqueous $\mathrm{Ag} / \mathrm{Ag}^{+}$was used as reference electrode (10 $\mathrm{mM} \mathrm{AgNO}_{3}$ in $0.1 \mathrm{M} \mathrm{Bu}_{4} \mathrm{NPF}_{6}$ in acetonitrile), platinum wire as counter electrode and glassy carbon as the working electrode for all measurements. All $E_{1 / 2}$ potentials are directly obtained from cyclic voltammetric curves as averages of the cathodic and anodic peak potentials. Ferrocene was used as an internal standard. The standard potential of ferrocinium/ferrocene couple in THF $(+0.085 \mathrm{~V})$ was used to calibrate all voltammetry plots. High-resolution mass spectra (HRMS) recorded for accurate mass analysis, were performed on Thermo scientific Q Exactive HF. The ECD spectrometer was purged with nitrogen before recording each spectrum, which was baseline subtracted. The baseline was always measured using the same solvent and in the same cell as the samples. The spectra are presented without smoothing and further data processing. VCD spectra were measured on ChiralIR-2X with $300 \mu \mathrm{m}$ cell, $\mathrm{CHBr}_{3}$ as solvent. The crystal structures were obtained from Rigaku XtalAB PRO MM007 DW.

\section{Computational methods}

The structural and energetic analyses of the molecular systems for all compounds described in this study were carried out with the B97-D dispersion enabled density functional method, ${ }^{29,30}$ using an ultrafine grid, together with the Def2TZVPP basis set. $^{31}$ Full geometry optimizations were performed and uniquely characterized via second derivatives (Hessian) analysis to establish stationary points and effects of zero point and thermal energy contributions. Absorption energies were computed in acetonitrile at the TD-wB97 $\mathrm{xD}^{32} / \mathrm{Def} 2-$ TZVPP(ACN) level of theory. From the TD-DFT results, spectra were simulated from the excitation energies and rotation lengths by overlapping Gaussian functions for each transition. VCD was performed in bromoform at the B97-D/Def2-TZVPP $\left(\mathrm{CHBr}_{3}\right)$ level of theory. The simulated VCD spectrum consists of a sum of Lorentzian distributions centered on the computed frequencies, with fixed width and with the height proportional to the computed rotational constant. Reduction potential data was determined in tetrahydrofuran at the B97-D/Def2-TZVPP (THF) level of theory, using $E^{\circ}=-\Delta H / n F$, where $n=1, F=1 \mathrm{eV}$, and referenced to $\mathrm{Ag} / \mathrm{AgCl}$. The Strumm and Morgan correction $^{33}$ for $0.1 \mathrm{M} \mathrm{AgCl} / \mathrm{Ag}$ of 0.29 was used in combination with the value for the SHE electrode, giving $4.73=4.44(\mathrm{SHE})+0.29$ (0.1 M AgCl/Ag), for the reference value. Effects of solvent employed the COSMO:ab initio continuum method ${ }^{34,35}$ using a dielectric as in experiment, and radii of Klamt. ${ }^{36}$ Visualization and analysis of structural and property results were obtained using Avogadro ${ }^{37}$ and GaussView (for spectra). ${ }^{38}$

1 Y. Srintana-Anant, T. J. Seiders and J. S. Siegel, Design of Novel Aromatics using the Loschmidt Replacement of Graphs, Top. Curr. Chem., 1998, 196, 1-44.

2 K. K. Baldridge and J. S. Siegel, Of Graphs and Graphenes: Molecular Design and Chemical Studies of Aromatic Compounds, Angew. Chem., Int. Ed., 2013, 52, 5436-5438.

3 J. Loschmidt, Konstitutionsformeln der Organischen Chemie in Graphischer Darstellung, Wilhelm Engelmann, Leipzig, 1860.

4 A. Burger, Isosterism and bioisosterism in drug designin, Prog. Drug Res., 1991, 37, 287-371.

5 Y.-J. Cheng, S.-H. Yang and C.-S. Hsu, Synthesis of conjugated polymers for Organic solar cell applications, Chem. Rev., 2009, 109, 5868-5923.

6 M. E. Cinar and T. Ozturk, Thienothiophenes, dithienothiophenes, and thienoacenes: syntheses, oligomers, polymers, and properties, Chem. Rev., 2015, 115, 30363140. 
7 W. Jiang, Y. Li and Z. Wang, Heteroarenes as high performance organic semiconductors, Chem. Soc. Rev., 2013, 42, 6113-6127.

8 P. Kumaresan, S. Vegiraju, Y. Ezhumalai, S. L. Yau, C. Kim, W.-H. Lee and M.-C. Chen, Fused-thiophene based materials for organic photovoltaics and dye-sensitized solar cells, Polymers, 2014, 6, 2645-2669.

9 D. Xie, T. Liu, W. Gao, C. Zhong, L. Huo, Z. Luo, K. Wu, W. Xiong, F. Liu, Y. Sun and C. Yang, A novel thiophenefused ending group enabling an excellent small molecule acceptor for high-performance fullerene-free polymer solar cells with $11.8 \%$ efficiency, Sol. RRL, 2017, 1, 1700044.

10 C. Zhang and X. Zhu, Thieno[3,4-b]thiophene-based novel small-molecule optoelectronic materials, Acc. Chem. Res., 2017, 50, 1342-1350.

11 R.-Q. Lu, Y.-N. Zhou, X.-Y. Yan, K. Shi, Y.-Q. Zheng, M. Luo, X.-C. Wang, J. Pei, H. Xia, L. Zoppi, K. K. Baldridge, J. S. Siegel and X.-Y. Cao, Thiophene-fused bowl-shaped polycyclic aromatics with a dibenzo[a,g]corannulene core for organic fieldeffect transistors, Chem. Commun., 2015, 51, 1681-1684.

12 L. Meng, T. Fujikawa, M. Kuwayama, Y. Segawa and K. Itami, Thiophene-fused pi-systems from diarylacetylenes and elemental sulfur, J. Am. Chem. Soc., 2016, 138, 1035110355.

13 V. Rajeshkumar and M. C. Stuparu, A photochemical approach to aromatic extension of the corannulene nucleus, Chem. Commun., 2016, 52, 9957-9960.

14 B. Topolinski, B. M. Schmidt, M. KathaN, S. I. Troyanov and D. Lentz, Corannulenylferrocenes: towards a 1D, noncovalent metal-organic nanowire, Chem. Commun., 2012, 48, 6298-6300.

15 Y. Wang, O. Allemann, T. S. Balaban, N. Vanthuyne, A. Linden, K. K. Baldridge and J. S. Siegel, Chiral atropisomeric indenocorannulene bowls: critique of the cahningold-prelog conception of molecular chirality, Angew. Chem., Int. Ed., 2018, 57, 6470-6474.

16 Y.-T. Wu, D. Bandera, R. Maag, A. Linden, K. K. Baldridge and J. S. Siegel, Multiethynyl corannulenes: synthesis, structure, and properties, J. Am. Chem. Soc., 2008, 130, 10729-10739.

17 X. Tian, L. M. Roch, K. K. Baldridge and J. S. Siegel, Diindenocorannulenes : curved aromatics blending bowlin- bowl assembly and nanocarbon material properties, Eur. J. Org. Chem., 2017, 2017, 2801-2805.

18 N. B. Karroum, C. Patinote, C. Deleuze-Masquéfa, G. Moarbess, M. Diab-Assaf, P. Cuq, I. Kassab and P.-A. Bonnet, Methylation of imidazopyrazine, imidazoquinoxaline, and pyrazoloquinoxaline through Suzuki-Miyaura cross coupling, Chem. Hetero. Comp., 2018, 54, 183-187.

19 G. A. Molander, B. W. Katona and F. Machrouhi, Development of the Suzuki-Miyaura cross-coupling reaction: use of air-stable potassium alkynyltrifluoroborates in aryl alkynylations, J. Org. Chem., 2002, 67, 8416-8423.

20 X. Tian, L. M. Roch, N. Vanthuyne, J. Xu, K. K. Baldridge and J. S. Siegel, Azaindenocorannulenes: Synthesis, Properties, and Chirality, Org. Lett., 2019, 21, 3510-3513.
21 B. D. Steinberg, E. A. Jackson, A. S. Filatov, A. Wakamiya, M. A. Petrukhina and L. T. Scott, Aromatic $\pi$-systems more curved than $\mathrm{C}_{60}$. the complete family of all indenocorannulenes synthesized by iterative microwave-assisted intramolecular arylations, J. Am. Chem. Soc., 2009, 131, 1053710545.

22 L. Shi, L. M. Roch, O. Allemann, J. Xu, N. Vanthuyne, K. K. Baldridge and J. S. Siegel, 1,2,3- versus 1,2-indeno ring fusions influence structure property and chirality of corannulene bowls, J. Org. Chem., 2018, 83, 39793986.

23 T. B. Freedman, X. Cao, R. K. Dukor and L. A. Nafie, Absolute Configuration Determination of Chiral Molecules in the Solution State Using Vibrational Circular Dichroism, Chirality, 2003, 15, 743-758.

24 T. J. Seiders, K. K. Baldridge, G. H. Grube and J. S. Siegel, Structure/Energy Correlation of Bowl Depth and Inversion Barrier in Corannulene Derivatives: Combined Experimental and Quantum Mechanical Analysis, J. Am. Chem. Soc., 2001, 123, 517-525.

25 G. Marino, A quantitative study of the uncatalysed halogenation of thiophene in acetic acid solution, Tetrahedron, 1965, 21, 843-848.

26 G. Marino, Quantitative aspect of electrophilic substitution in furan, thiophene, pyrrole, and other five-membered heteroaromatic systems (Review), Chem. Heterocycl. Compd., 1973, 9, 537-545.

27 Y. L. Gol'dfarb, V. P. Litvinov and S. A. Ozolin, Researches in the thiophene series, Chem. Heterocycl. Compd., 1965, 1, 445-457.

28 P. Linda and G. Marino, Electrophilic substitution in fivemembered heterocyclic systems. Part VI. Kinetics of the bromination of the 2-methoxycarbonyl derivatives of furan, thiophen, and pyrrole in acetic acid solution, J. Chem. Soc., 1968, 1968, 392-394.

29 S. Grimme, J. Comput. Chem., 2006, 27, 1787-1799.

30 S. Grimme, J. Chem. Phys., 2006, 124, 034108-034115.

31 F. Weigend and R. Ahlrichs, Phys. Chem. Chem. Phys., 2005, 7, 3297-3305.

32 J. D. Chai and M. Head-Gordon, J. Chem. Phys., 2008, 128, 084106.

33 W. Strumm and J. J. Morgan, Aquatic Chemistry: Chemical Equilibria and Rates in Natural Waters, Wiley-Interscience, New York, 1996.

34 A. Klamt and G. Schüürmann, J. Chem. Soc. Perkin Trans. 2, 1993, 799.

35 K. K. Baldridge and A. Klamt, J. Chem. Phys., 1997, 106, 6622-6633.

36 A. Klamt, V. Jonas, T. Bürger and C. W. Lohrenz, J. Phys. Chem., 1997, 102, 5074.

37 M. D. Hanwell, D. E. Curtis, D. C. Lonie, T. Vandermeersch, E. Zurek and G. R. Hutchison, J. Cheminf., 2012, 4, 17.

38 R. Dennington, T. Keith and J. Millam, GaussView, Version 5, Semichem Inc., Shawnee Mission, KS, 2009. 